\title{
Ultramafic rocks in the Kurosegawa tectonic zone, Southwest Japan
}

\author{
KAZUMI YOKOYAMA \\ Department of Geology, National Science Museum \\ Shinjuku-ku Hyakunin-cho 3-23-1, Tokyo 160, Japan
}

\begin{abstract}
The Kurosegawa tectonic zone extends from Kyushu to the western Kii Peninsula and con tains ultramafic rocks with two distinct textural and chemical types of olivine and clinopyroxene. The ultramafic bodies were mainly harzburgites or lherzolites which originally equilibrated at around amphibolite facies conditions and subsequently re-equilibrated near $400^{\circ} \mathrm{C}$. Ultramafic rocks in the Chichibu belt, from the eastern Kii Peninsula to the Kanto Mountains, have the same textural and chemical characteristics as those in the Kurosegawa tectonic zone ; accordingly, they are considered to be an eastern extension of the zone.

Petrology of the ultramafic rocks and the distribution of lithologic types within the Kurosegawa tectonic zone indicate that the ultramafic rocks and the associated granitic and high-grade metamorphic rocks were originally situated towards the western side of the zone, and were tectonically sliced and crushed by left-lateral movement during the Early Cretaceous. The more mobile serpentinized ultramafic rocks were transported laterally far to the east along the strikeslip systems, but the other rigid materials remained within the western area.
\end{abstract}

\section{Introduction}

Mappable bodies of deformed rocks char acterized by the inclusions of indigenous and exotic blocks are defined as "mélange" by Hsü (1968). The matrix material of mélange is mostly pelitic-psammitic, although serpentinite-matrix mélange is not uncommon (e.g. Saleeby, 1979 ; Ivanov and Baratov, 1974). The Kurosegawa tectonic zone is such a serpentinite mélange situated in the middle of the Chichibu belt (Fig. 1) which is a Jurassic accre- tion complex composed of Jurassic clastics and Late Paleozoic to Early Mesozoic oceanic (nonclastic) sediments and volcanics (Maruyama, 1981 ; Saito, 1985). The serpentinite mélange sometimes splits to form minor branches, but all of these lie within the Chichibu belt and contacts with the Chichibu formations are usually high angle faults (Ichikawa et al., 1956; Maruyama, 1981).

The Kurosegawa tectonic zone (Fig. 2) was originally defined by Ichikawa et al. (1956) as lying zone within the Chichibu belt and contain-

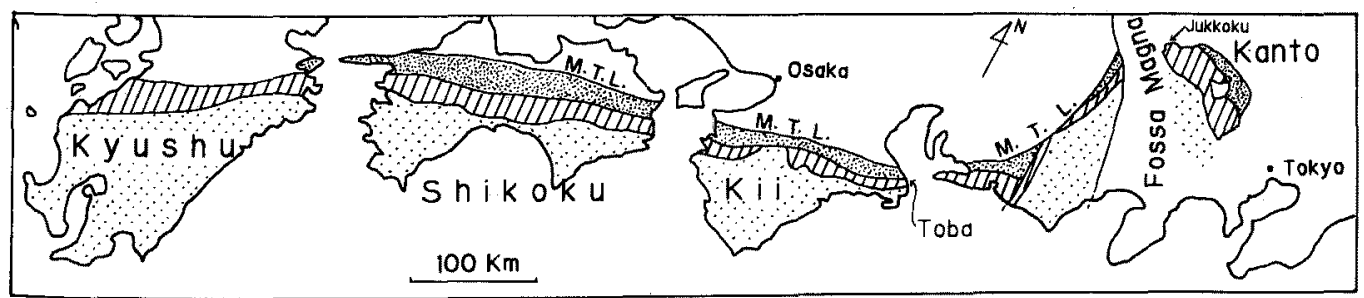

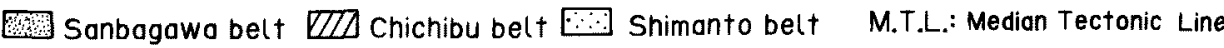

Fig. 1. Distribution of tectonic belts of Southwest Japan.

(Manuscript received, April 9, 1987;

accepted for publication, July 16, 1987) 


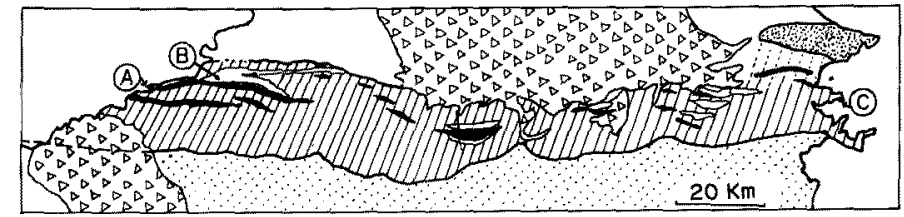

Ky ushu

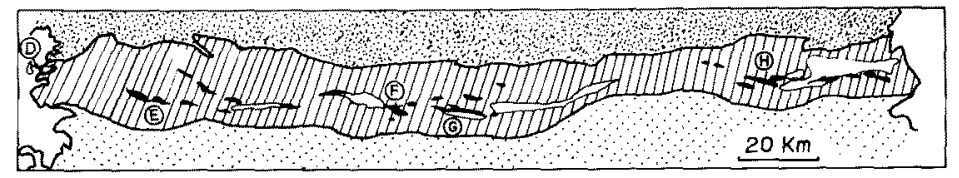

$\mathrm{Sh} \mathrm{Kok}$
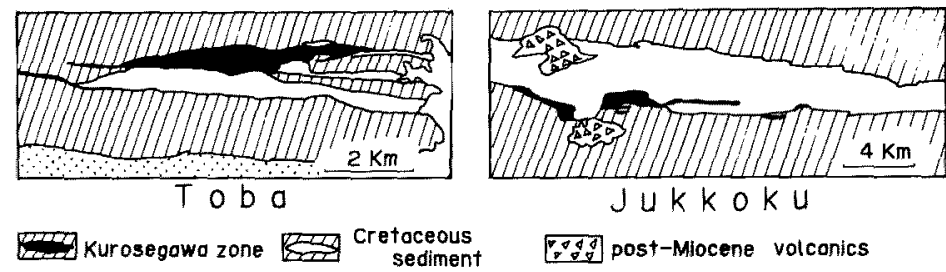

$\mathrm{Jukkoku}$

[8. 0 post-Miocene valconics

Fig. 2. Enlargements of Fig. 1 showing distributions of constituents of the Kurosegawa zone and the Early Cretaceus sediment in the Chichibu belt. Symbols for the three major tectonic belts are the same as Fig. 1. Maps are simplified from those by Hirokawa et al. (1978), Yamagiwa (1957) and Inoue (1974).

A, Tanoura; B, Sakamoto; C. Tsukumi ; D, Mikame; E, Terano; F, Jitsuma; G, Engyoji and Ino; H, Sakashu.

ing granitic rocks, gneiss and Siluro-Devonian formations. However, recent geological study shows that the Kurosegawa mélange includes many units similar in age and lithology to those in the Chichibu belt (Maruyama et al., 1984). As discussed later, rocks which are definitely exotic within Chichibu belt are treated here as the constituent members of the Kurosegawa zone, similar to the original definition except for the additional recognition of the ultramafic components. Rock fragments in the mélange are classified into four groups: SilurianDevonian sedimentary rocks; granitic and high-grade metamorphic rocks of ca. $400 \mathrm{Ma}$ (e.g. Hayase and Ishizaka, 1967; Ishizaka, 1972); high-pressure metamorphic rocks with various metamorphic ages (220-420 Ma); and ultramafic rocks associated with mafic rocks. These four lithological groups occur mostly as lenticular bodies in serpentinite matrix or along faults in the Chichibu belt, and they have been affected by weak metamorphism which produced prehnite, chlorite and epidote. Early Cretaceous shallow-marine and brackishwater sediments occur commonly along the zone (Matsumoto et al., 1982), usually in fault contact with the mélange and with Chichibu formations.

The Kurosegawa tectonic zone and the associated Cretaceous sediments extend eastwest for about $500 \mathrm{~km}$ from the western end of the Kii Peninsula through Shikoku to Kyushu in Southwest Japan (Fig. 1 and 2). In the eastern part of the Chichibu belt, serpentinite mélanges with inclusions only of peridotites and gabbroic rocks occur intermittently and are adjacent to Cretaceous sediments. The constituent large mélanges are in the eastern part of the Kii Peninsula and the Kanto Mountains (Fig. 2). Peridotites in such areas have the same mineralogical and petrological characteristics as the included blocks in Shikoku and Kyushu and 
therefore these serpentinite mêlanges are considered to be an eastern extension of the Kurosegawa zone.

Within the mélange, the Silurian-Devonian sedimentary rocks consist of limestone, shale and volcaniclastics. Granitic rocks are mostly granodiorite. High-grade metamorphic rocks are amphibolite, garnet amphibolite, granulite and biotite gneiss. Sr-Rb and $\mathrm{K}-\mathrm{Ar}$ ages of the granitic rocks and high-grade metamorphic rocks have been determined as $c a .400 \mathrm{Ma}$ (Maruyama et al., 1984). High-pressure metamorphic rocks are jadeite- and lawsonitebearing rocks and spotted schist with isotope ages of 220-420 Ma (Maruyama et al., 1984).

\section{Kurosegawa ultramafic rocks}

Matrix materials of the mêlange are always finely crushed, fine-angular or lenticular serpentinites. Peridotite, clinopyroxenite, chromitite and rodingite rarely occur as podlike or lenticular bodies in the serpentinitematrix with thicknesses mostly less than $3 \mathrm{~m}$. One large ultramafic body, more than $100 \mathrm{~m}$ thick, is located at the western end (Mikame) of Shikoku.

Two textural types of olivine and clinopyroxene are commonly present in the peridotites and clinopyroxenites, often in the same thin section, and are found in all localities from the Kanto Mountains to Kyushu. One is coarsegrained olivine and clinopyroxene with granular texture similar to Alpine-type peridotites and nodules in alkali-basalt (Mercier and Nicolas, 1975), and with size usually greater than $0.5 \mathrm{~mm}$ in optically continuous grains (Fig. $3 \mathrm{~A}$ and $\mathrm{B}$ ). The other type is fine-grained olivine (Fig. 3B and C) and clinopyroxene (Fig. 3D), usually accompanied by serpentine and magnetite. The fine-grained olivines are mostly aggregates of anhedral to tabular crystals with different optical orientations which sometimes form a large mosaic grain com- prised of many small individuals (Fig. 3C) and more rarely occur as a narrow film at a grain boundary between coarse-grained olivines. The fine-grained clinopyroxene is usually acicular to rectangular (Fig. 3D) and it is present even in completely serpentinized rock, sometimes within the fine-grained olivine mosaic (Fig. 4B).

The two distinct textural types of olivine and clinopyroxene in ultramafic rocks of the Kurosegawa zone are similar to those in serpentinized peridotite subjected to contact metamorphism (Frost, 1975 ; Pinsent and Hirst, 1977 : Dungan, 1977) or regional metamorphism (Peters, 1968; Trommsdorff and Evans, 1972; Hoffman and Walker, 1978). In common with such metamorphosed peridotites, ultramafic mineral textures and compositions within the Kurosegawa zone suggest that the coarsegrained phases are remnants of early stage equilibration and the fine-grained minerals are secondary products formed by later equilibration. In this connection, the term "primary" denotes the early stage equilibration and "secondary" referes to the later stage.

Peridotite and serpentinite. Although most of the peridotites are extensively serpentinized, some are composed of more than $60 \%$ primary modal olivine. The peridotites carry a granular texture (Fig. 3A) and consist of olivine with trace amounts of clinopyroxene and chromian spinel. Orthopyroxene is found in a few samples, but it must have been a major original constituent in the peridotites because bastite pseudomorphs are not uncommon. Olivine is replaced by serpentine along rims and in cores. Clinopyroxene is blastoporphyritic in the peridotite. Most of the crystals are dusty and are sometimes surrounded by overgrowths of clean clinopyroxene.

In the peridotites, except for those in the Mikame area, the modal percentage of clinopyroxene is usually less than 10 and $\mathrm{CaO}$ 


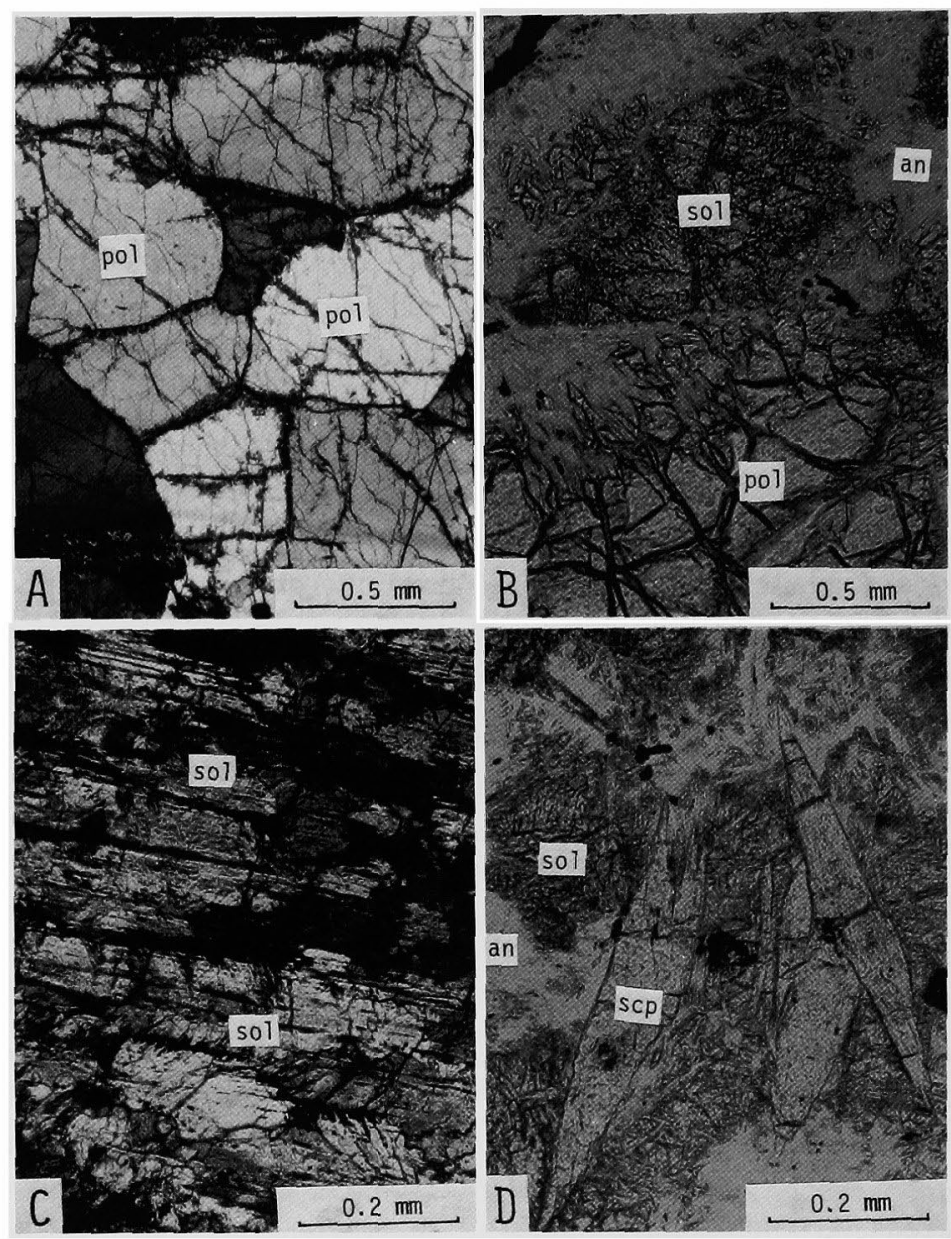

Fig. 3. Photomicrographs of olivine and clinopyroxene textures.

A ; Primary olivines (pol) showing granular texture with antigorite developed only at the grain boundaries. B; Serpentinized primary olivine (pol) and secondary olivine aggregate (sol). C ; Mosaic texture of secondary olivines, each with a different optical orientation. D; Acicular to rectangular clinopyroxene ( $\mathrm{scp}$ ) associated with secondary olivine and antigorite (an).

contents of the ultramafic rocks from the Kanto Mountains are from 0.5 to $2.3 \mathrm{wt} \%$ (Hirano and Iizumi, 1973). As bastite after orthopyroxene is common, original rock-types of the peridotites are considered to be harzburgite or lherzolite and bulk compositions of serpentinites from Shikoku support a harzburgitic origin (Hayashi, 1968). In the Mikame area, clinopyroxene-rich peridotites are as prevalent as the clinopyroxene-poor peridotites, consisting primarily of clinopyroxene and olivine with a trace amount of spinel and rarely with orthopyroxene which is partly or completely replaced by an acicular clinopyroxene-serpentine aggregate (Fig. 4C). The modal composition of clinopyroxene and rare occurrence of orthopyroxene or its pseudomorph suggest that the Mikame rocks belong to the dunite-wehrlite series, but textural features of the mineral assemblages are the same as those in the other areas.

Secondary minerals in the peridotites are 


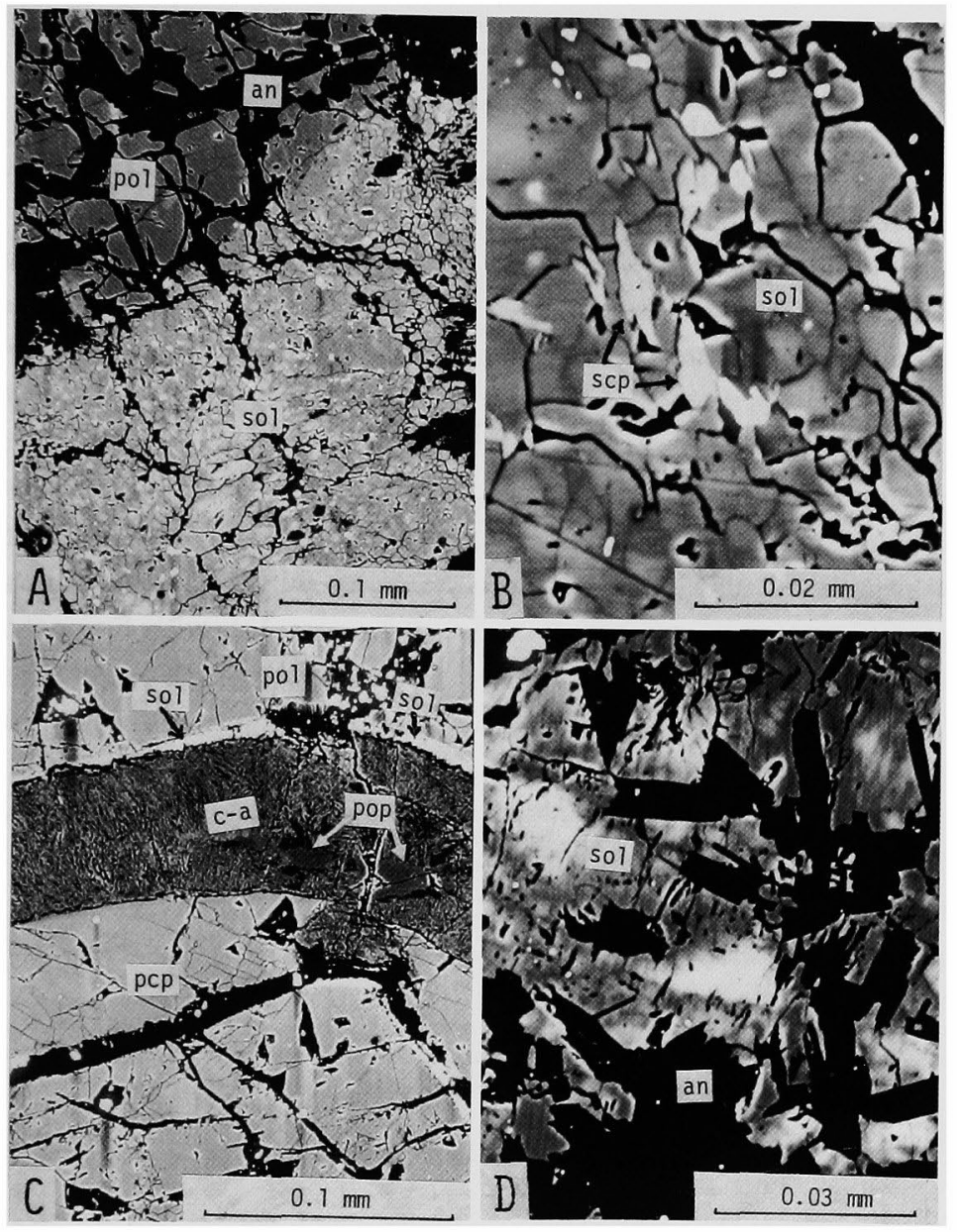

Fig. 4. Back-scattered electron images of minerals in the ultramafic rocks.

A ; Primary and secondary olivines. Secondary olivines are associated with acicular clinopyroxene. B ; Acicular clinopyroxene in secondary olivine aggregate. C; Primary orthopyroxene (pop) occurring between primary olivine and clinopyroxene. Othopyroxene has almost completely decomposed into acicular clinopyroxene serpentine aggregate (c-a). Secondary olivine (Fo 65-76) occurs between primary olivine (Fo 82 ) and the aggregate. D ; Heterogeneous secondary olivines (compositional traverse as in Fig. 7B).

fine-grained olivine and acicular clinopyroxene, serpentine, brucite, magnetite, chlorite and amphibole. Serpentine minerals are mostly antigorite in the serpentinized peridotites and massive serpentinites, whereas chrysotile/lizardite are predominant in the finely crushed and fine-angular serpentinites. Antigorite normally shows a flame-like radiating blade texture or a lepidoblastic fabric of anhedral blades replacing primary olivine (Fig. 3 ). In the peri- dotites, chrysotile/lizardite occurs as pseudomorphs after olivine or as vein minerals. Amphibole is rarely found around clinopyroxene in the peridotites from Kyushu and western Shikoku and magnetite is ubiquitous in serpentinized matrices. Carbonate minerals occur occasionally as vein minerals crosscutting a serpentinite matrix.

Clinopyroxenite. Clinopyroxenite consists of clinopyroxene and a subordinate amount of 
olivine, orthopyroxene, hornblende and spinel as accessory minerals. Most of the clinopyroxenites appear black to the naked eye and are composed mainly of primary clinopyroxene, but some are pale greenish to white and consist only of secondary clinopyroxene. Primary dusty clinopyroxene sometimes has overgrowths of secondary clinopyroxenes with the same optical orientation. Orthopyroxene is partly replaced by serpentine and fibrous clinopyroxene aggregate. Amphibole is present as an overgrowth mineral on primary clinopyroxene or as an acicular mineral in serpentine-rich assemblages.

Chromitite. Chromitite is found in all the areas, consisting primarily of chromite and olivine with chlorite, serpentine, uvarovite and magnetite as secondary minerals.

Rodingite. Rodingite is mostly in pod-forms with diameters from $30 \mathrm{~cm}$ to about $10 \mathrm{~m}$. It contains mainly grossular, clinopyroxene and chlorite with subordinate amounts of sphene and pectolite sometimes showing a concentric zonal structure. Chlorite-sphene and pectolite-chlorite zones are common between the rodingite and serpentinite with prehnite veins developed only in the central part. Hornblende and blastoporphyritic clinopyroxene are seen in large rodingite bodies, but it is not clear whether the original rock-type of the rodingites is amphibolite or hornblende-gabbro.

\section{Chemical compositions of minerals}

Mineral compositions were determined by WDS (JEOL XMA 5) using the method described by Nakamura and Kushiro (1970) and by EDS (Link systems) with the ZAF method of Statham (1979). Precision and detection limits of the EDS (Link systems) were discussed by Dunham and Wilkinson (1978, 1980). In the analyses of the minor elements in olivine, background corrections against $\mathrm{X}$-ray peak intensities were made with WDS by counting at wavelengths both below and above the peak, with a counting time at each point of 200 seconds. The representative analyses are shown together with the textural type in Table 1.

Olivine. Primary olivines in individual thin sections are remarkably homogeneous within a range in forsterite content (Fo) of less than 1. Fo contents of the primary olivine are $89-93$ in the peridotites from the areas studied except for the Mikame region where the range is from 80 to 93 (Fig. 5). Secondary olivines are homogeneous within a single thin section from most of the samples, with Fo contents from 85 to 96 . Secondary olivine associated with acicular clinopyroxene and serpentine has lower Fo contents than the primary olivine in the same thin section (Fig. 4A), whereas secondary

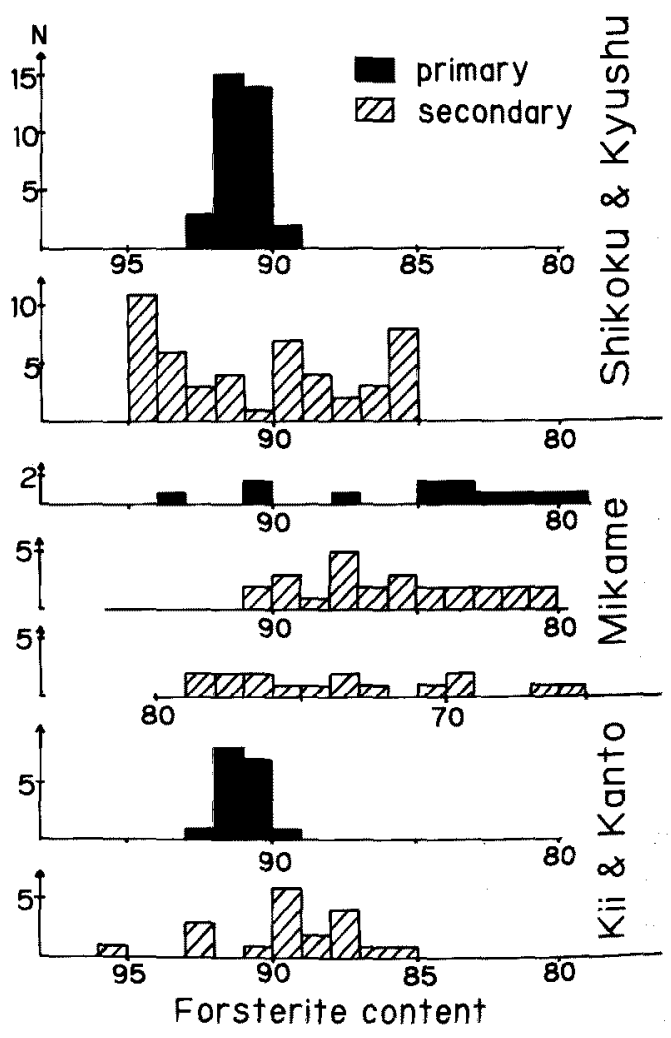

Fig. 5. Forsterite contents of primary and secondary olivines. Vertical axis is number of analyses. 
Table la. Chemical compositions of minerals in ultramafic rocks in Shikoku

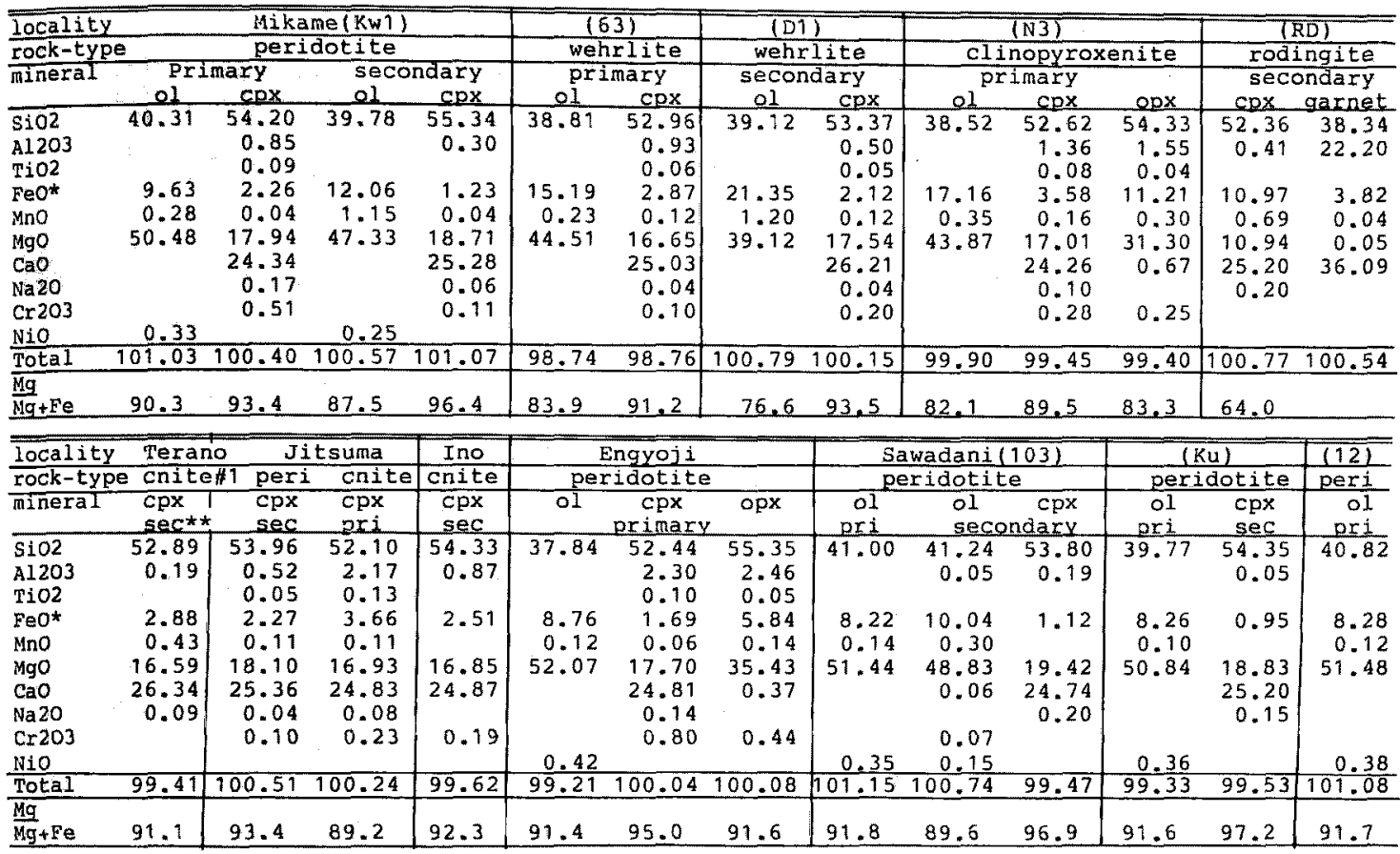

*Total Fe as Feo **sec;secondary, pri;Primary, \# cnite;clinopyroxenite, wehr; wehrlite

Table 1b. Chemical compositions of minerals in ultramafic rocks in Kyushu



* Total Fe as Feo, ** pri;primary. sec;secondary 
Table lc. Chemical compositions of minerals in ultramafic rocks from Kii Peninsula and Kanto Mountains.

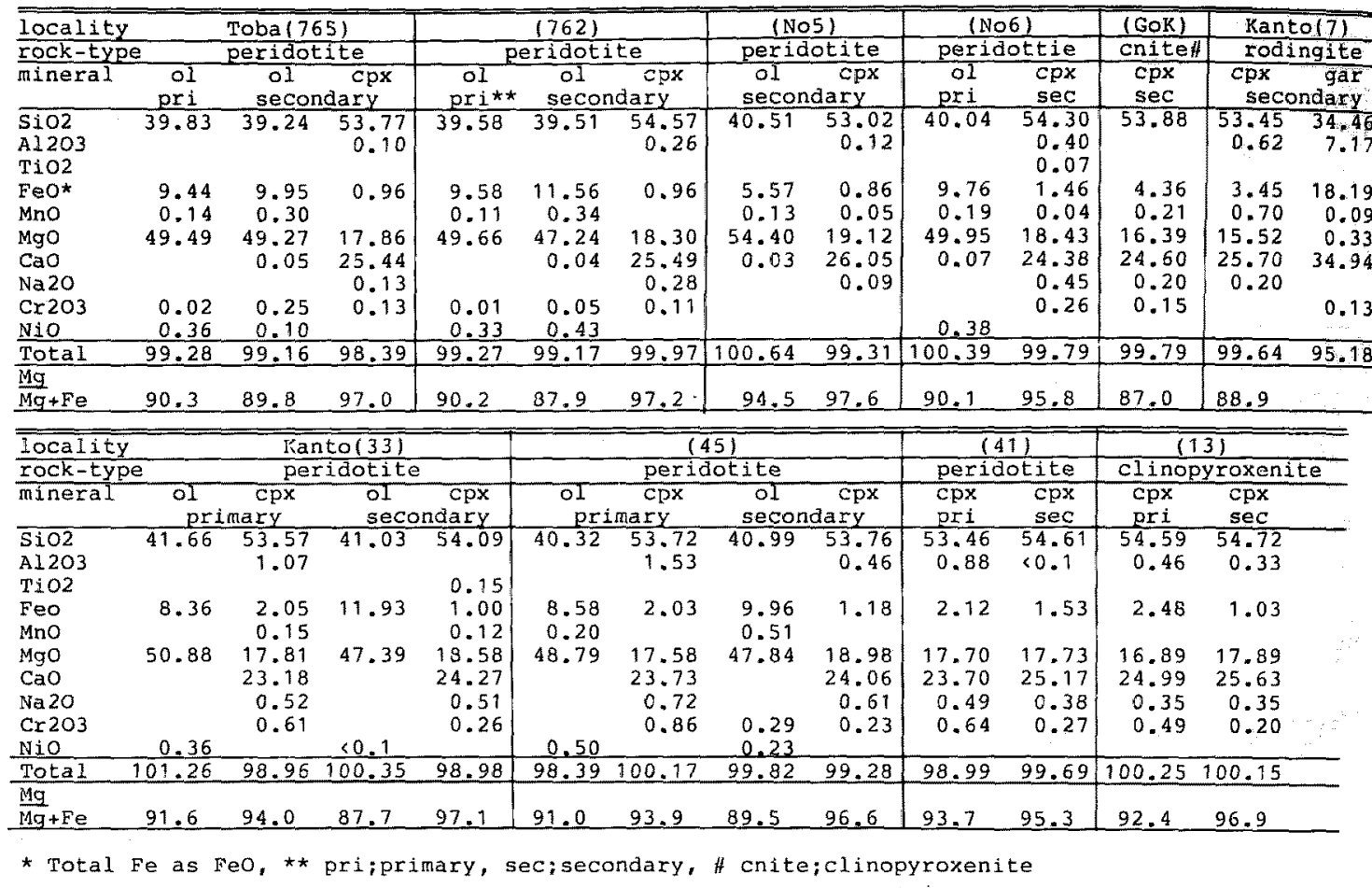

olivine associated with magnetite has higher Fo contents than the primary olivine (Fig. 7A). As shown in Fig. 5 , both the primary and secondary olivines from Shikoku and Kyushu, in typical areas of the Kurosegawa tectonic zone, are not different in Fo contents from those in the eastern Kii Peninsula and Kanto Mountains which are treated here as the eastern extension of the zone.

In two samples of wehrlites from the Mikame area, secondary olivines are quite heterogeneous. In one sample where primary olivine is Fo 89, the composition of secondary olivines ranges from 74 to 87 and an oscillatory pattern is observed in a microprobe traverse (Fig. 7B). In the other sample, fine-grained olivine occurring as a film at the boundary between primary olivine ( $F_{0} 82$ ) and clinopyroxene-serpentine aggregate (Fig. $4 \mathrm{C}$ ) has Fo contents ranging from 65 to 76 .
Obvious compositional differences in the content of minor elements are found between primary and secondary olivines (Fig. 6). Secondary olivine has mostly higher $\mathrm{MnO}$, up to 1.2
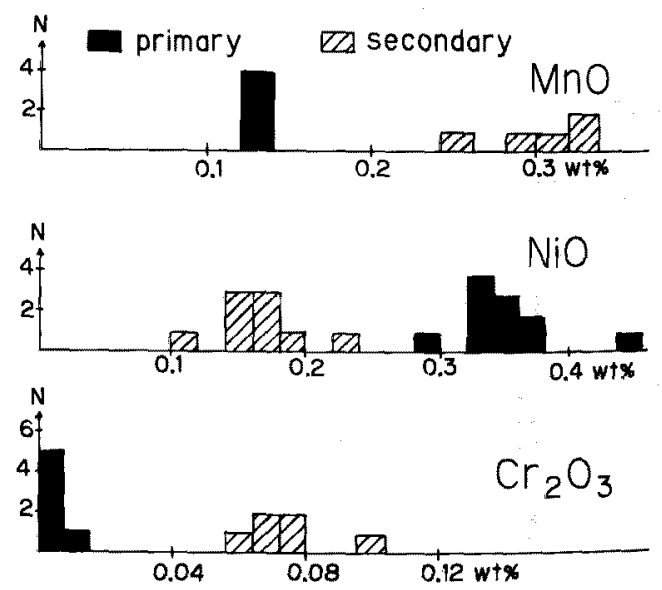

Fig. 6. Differences in trace elements between primary and secondary olivines within a single thin section. 

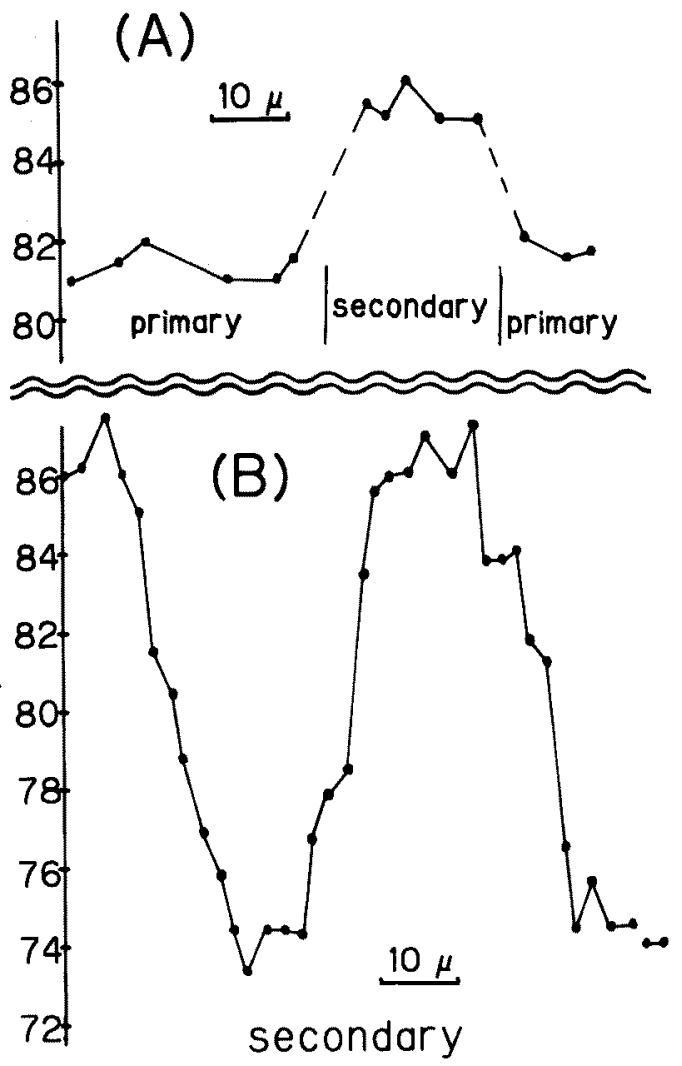

Fig. 7. Forsterite content in compositional profiles of olivine.

A ; secondary olivine, accompanied by magnetite, formed at the grain boundary between primary olivines. B heterogeneous secondary olivine shown in Fig. $4 \mathrm{D}$.

wt\%, and lower $\mathrm{NiO}$ sometimes less than 0.2 wt\%. Such high $\mathrm{MnO}$ and low $\mathrm{NiO}$ contents have been reported in metamorphic olivines coexisting with antigorite from East Dover in Vermont (Hoffman and Walker, 1978), Malenco in Italy (Trommsdorff and Evans, 1980), Blue River in British Columbia (Pinsent and Hirst, 1977) and Cascade Mountains in Washington (Vance and Dungan, 1977). The metamorphic olivines are reported to have Fo contents usually greater than 90 , but $\mathrm{MnO}$ contents are relatively high, up to $1.6 \mathrm{wt} \%$, and $\mathrm{NiO}$ is mainly less than $0.2 \mathrm{wt} \%$.

Clinopyroxene. In the peridotites, both the

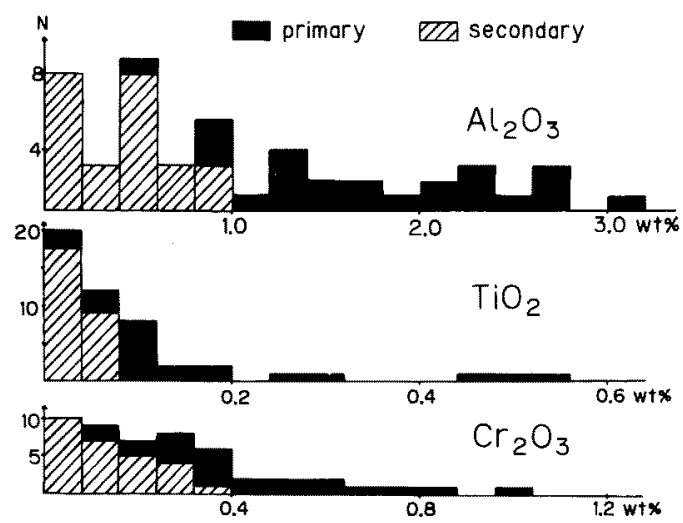

Fig. 8. Differences in minor element between primary and secondary clinopyroxenes.

primary and secondary clinopyroxenes are chemically homogeneous in a single thin section. Compositional differences between the primary and secondary clinopyroxenes are found in minor element contents, as with olivines. The primary clinopyroxenes are usually rich in $\mathrm{Al}_{2} \mathrm{O}_{3}, \mathrm{TiO}_{2}$ and $\mathrm{Cr}_{2} \mathrm{O}_{3}$ (Fig. 8). Their $\mathrm{Mg} /(\mathrm{Mg}+\mathrm{Fe})$ ratios are usually less than 95 , whereas the ratios for secondary clinopyroxenes in peridotites are usually more than 95 .

On the other hand, most of the secondary clinopyroxenes in clinopyroxenites and rodingites have variable $\mathrm{Mg} /(\mathrm{Mg}+\mathrm{Fe})$ ratios across a total range of 97 to 64 . Some samples are bimodal within the ratio values, apparently showing a compositional gap between 94 and 85. It is, however, not yet clear whether this is due to a miscibility space or to other secondary effects because the compositional break is not fixed within the ratio and it is not present in all the samples.

Other minerals. Most of the secondary minerals are chemically homogeneous and, apart from garnet and amphibole, show no systematic variation between samples. Garnets in the ultramafic rocks are andradite and uvarovite, whereas rodingites contain grossular or hydrogrossular. Amphibole is tremolite to richterite. 


\section{Petrogenesis}

Two textural types of olivine and clinopyroxene are present in peridotites in the Kurosegawa tectonic zone from Kyushu to the Kanto Mountains and the compositional differences in minor element contents suggest that these peridotites have undergone at least two phases of equilibration in primary and secondary stages. Primary stage. Most of the peridotites were composed originally of coarse-grained olivine and orthopyroxene with subordinate amounts of clinopyroxene and spinel. Based on mineral assemblages in less serpentinized samples, the parent rock-types of the peridotites, except those in the Mikame area, are considered to have been mainly harzburgite or lherzolite associated with minor clinopyroxenite and chromitite. Forsterite contents of the primary olivines are from 89 to 93 (Fig. 5). In the Mikame area, wehrlites were as common as the clinopyroxene-poor peridotites, and $F_{0}$ contents of olivines are between 74 and 95 . Clinopyroxenite and chromitite are present in all areas from Kyushu to the Kanto Mountains.

Temperatures of equilibration of the primary assemblages are estimated using the $\mathrm{Mg}$ $\mathrm{Fe}$ partitioning between clinopyroxene and olivine and/or orthopyroxene (Mori and Banno, 1973 ; Mori and Green, 1978 ; Yokoyama, 1982). The $\mathrm{Mg}-\mathrm{Fe}$ partitioning between clinopyroxene and olivine is shown graphically in Fig. 9 where the plots for primary clinopyroxene-olivine pairs from the Kurosegawa tectonic zone fall in the area between curves for the Higashi-akaishi and Almkloudalen (Norway) peridotites. The average of the $\mathrm{Mg}-\mathrm{Fe}$ partition coefficient between coexisting clinopyroxene and orthopyroxene is 1.7 , which is between 2.0 for the Higashi-akaishi and 1.4 for the Norway pairs. The results obtained by two independent thermometers are consistent, showing that the

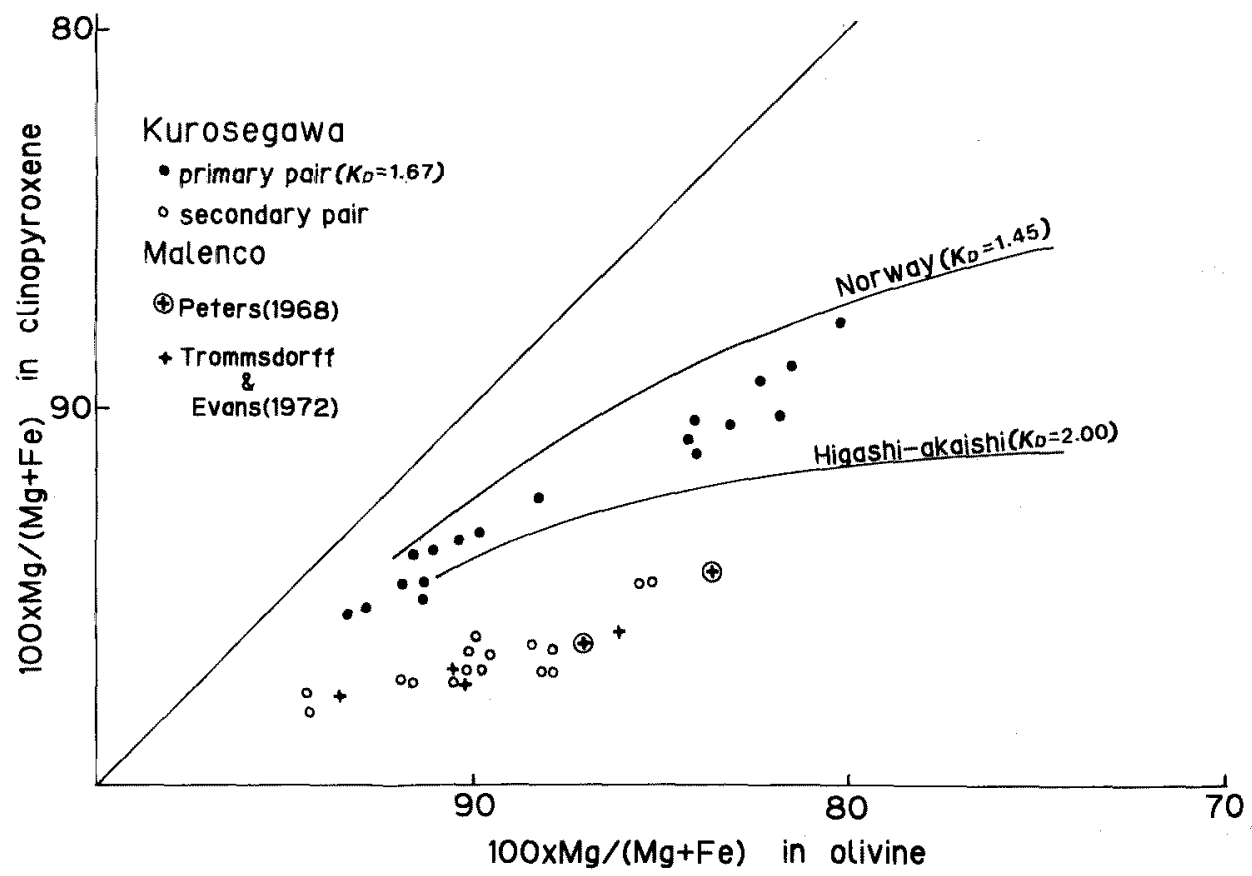

Fig. 9. Fe-Mg partition between olivine and clinopyroxene. $\mathrm{K}_{\mathrm{D}}$ in parenthesis is $\mathrm{Fe}-\mathrm{Mg}$ partition coefficient between clino- and orthopyroxenes. Lines for Norway and Higashi-akaishi are from Mori and Banno (1973). 
ultramafic rocks in the Kurosegawa tectonic zone equilibrated primarily at temperatures between those for the Higashi-akaishi and Norway peridotites.

Metamorphic rocks associated with the Higashi-akaishi and Norway peridotites are epidote amphibolite and granulite facies, respectively, while the Kurosegawa peridotites are accompanied by garnet amphibolite, amphibolite, granulitic rocks and biotite gneisses which also belong to the same facies range. Equilibrium conditions of both the mafic and ultramafic rocks in the Kurosegawa tectonic zone were intermediate between the rocks from the Higashi-akaishi and from Norway. It is, however, unlikely that ultramafic rocks in the Kurosegawa tectonic zone were associated with the high-grade metamorphic rocks at the primary stage, because there is an absence of secondary stage equilibration in the high-grade metamorphic rocks as discussed later.

Mineral assemblages of the rodingites at the primary stage are not clear. As it is a mafic rock commonly associated with ultramafic bodies throughout all the areas, it is probable that both rock types equilibrated under amphibolite facies conditions.

Secondary stage. Secondary minerals in the ultramafic rocks are mainly antigorite, brucite, magnetite, fine-grained olivine and fine-grained clinopyroxene. Antigorite-brucite assemblages are common, associated with finegrained olivine, clinopyroxene and magnetite. The equilibrium relation of the minerals is as follows :

Olivine $+\mathrm{H}_{2} \mathrm{O}=$ serpentine + brucite

According to Johannes (1968), experimental temperatures for the equilibration (1) are near $450^{\circ} \mathrm{C}$ at a pressure range from 2 to $10 \mathrm{~kb}$. As most of the ultramafic rocks have antigoritebrucite assemblages, the temperature for ultramafic rocks will be less than $450^{\circ} \mathrm{C}$ and $\mathrm{H}_{2} \mathrm{O}$ pressure will be low in the olivine-bearing rocks.

The transition from chrysotile/lizardite to antigorite is determined experimentally as near $400^{\circ} \mathrm{C}$ (Moody, 1976). In regional metamorphism, the transition proceeds at about the upper stability limit of pumpellyite (Dietrich and Peters, 1971; Yokoyama, 1977). According to oxygen isotope studies in the New Caledonia metamorphic rocks (Black, 1974), pumpellyites in natural rocks decompose at around $400^{\circ} \mathrm{C}$. Hence, it will be reasonable to conclude that the secondary stage assemblages were equilibrated near to $400^{\circ} \mathrm{C}$.

Petrographical observations indicate that antigorite and brucite coexist with fine-grained olivine and clinopyroxene. Low temperature equilibration of the olivine and clinopyroxene is suggested by their $\mathrm{Fe}-\mathrm{Mg}$ partitioning. Fig. 9 shows that the secondary olivine-clinopyroxene pairs are equilibrated at lower temperature than those from the Higashi-akaishi peridotites where olivine is stable instead of the antigoritebrucite assemblage. The peridotites occur in the highest metamorphic grade in the Sanbagawa metamorphic belt and are surrounded by serpentinized peridotites with a stable assemblage of antigorite-brucite-olivine (Yokoyama, 1977 ; Kunugiza, 1984). The low temperature equilibration of the secondary olivine and clinopyroxene supports the concept that antigorite and brucite are equilibrated with secondary olivine and clinopyroxene. The olivine-clinopyroxene pairs from the Kurosegawa tectonic zone plot within a narrow range, as shown in Fig. 9, suggesting that all the peridotites re-equilibrated within restricted temperature limits as indicated by the presence of antigorite-brucite assemblages throughout the whole area.

Dungan (1977) concluded that secondary olivine has been formed from serpentinite by dehydration, and Pinsent and Hirst (1977) believed that mosaic lenticular olivines were 
derived from bastite serpentine pseudomorphs after orthopyroxene. Low $\mathrm{NiO}$ contents of some secondary olivines, as well as the texture of the mosaic aggregates, support the idea that they were formed from bastite after orthopy: roxene. However, it is not certain that all the secondary olivines were formed from bastite serpentine by dehydration because the petrogra phy shows that the primary olivine is replaced by antigorite, while bastite serpentine is transformed into olivine. The former reaction is hydration, whereas the latter is dehydration. Furthermore, $\mathrm{NiO}$ contents in the mosaic olivines are not always low, but range from 0.1 to $0.5 \mathrm{wt} \%$ and some mosaic aggregates contain clinopyroxene in equal amount to olivine.

Most of the ultramafic rocks are serpentinites containing antigorite-brucite associations; that is, they re-equilibrated mainly within the stability field of that assemblage. Nevertheless, other inclusions in the serpentine matrix, such as granitic rocks and high-grade metamorphic rocks have preserved the texture and chemical compositions of their original minerals. These included blocks have suffered only a weak metamorphism which locally produced prehnite, chlorite and epidote. The prehnite-chlorite assemblage equilibrates at temperatures lower than $250^{\circ} \mathrm{C}$ (Nitsch, 1971) and therefore, this assemblage must have formed at a different stage from the antigoritebrucite assemblage.

Generally, other metamorphic rocks coexisting with antigorite-brucite bearing ultramafic rocks have been equilibrated almost completely into epidote amphibolite or greenschist during regional or contact metamorphism (e.g. Pinsent and Hirst, 1977 ; Kunugiza, 1984). Mafic bodies included in the ultramafic rocks in such metamorphic terranes are rodingite consisting mainly of grossular and clinopyroxene (Yokoyama, 1977; Kunugiza, 1984). Hence, the rodingite and/or high-pres- sure metamorphic schists could possibly have been affected by the secondary stage of equili bration recorded in the ultramafic rocks. However, metamorphic minerals corresponding to the antigorite-brucite paragenesis are lacking in the Silurian-Devonian sediments, granitic rocks and high-grade metamorphic rocks which therefore could not have been associated with the ultramafic rocks at the secondary stage of equilibration. It follows that the preh. nite-chlorite assemblage, common in all the mafic to felsic rocks, must have formed after all the members in the Kurosegawa zone had been assembled tectonically.

The serpentinite matrix is composed mainly of crysotile/lizardite which are considered to crystallize at quite low temperatures near $100^{\circ} \mathrm{C}$, according to the oxygen isotope studies of Wenner and Taylor $(1971,1973)$. Presence of these assemblages, mostly in the serpentinite matrix, suggests that they developed at the latest stage and probably during or after the strike-slip faulting episode, discussed later.

\section{Genetic relations between the ultramafic rocks and other inclusions in the serpentinite matrix.}

At the primary stage, the ultramafic rocks in the Kurosegawa tectonic zone were peridotite, clinopyroxenite and chromitite which equilibrated at amphibolite facies temperatures and between those of the Higashi-akaishi and Norway peridotites. The enormous volume and originally anhydrous nature of the ultramafic rocks suggest that they were primarily located in the upper mantle. At the secondary stage they equilibrated mainly in the stability field of antigorite-brucite. The rodingite and high-pressure metamorphic rocks of the greenschist and epidote amphibolite facies have been possibly associated with the ultramafic rocks. The other inclusions in the serpentine mêlange were not present at the secondary 
stage of the ultramafic rocks, since they contain no evidence of such metamorphism. They must have been incorporated within the ultramafic rocks after the secondary stage.

After tectonic mixing of all the present members of the Kurosegawa tectonic zone, the whole association of lithologies suffered prehnite-chlorite metamorphism under different $\mathrm{P}$ $T$ conditions from the preceding generation of antigorite-brucite. Although prehnite and chlorite were commonly formed in rocks in the serpentine mélange, most of the secondary stage minerals in the ultramafic rocks were not altered; indeed, some crysotile/lizardite in the ultramafic rocks probably developed at or after the prehnite-chlorite stage. Prehnite-chlorite paragenesis occurred also in the Chichibu belt (Toriumi, 1975 ; Aiba, 1982), but it is not certain whether the assemblage represents the lowest grade of Sanbagawa regional metamorphism or formed only around the Kurosegawa tectonic zone.

\section{Summary and origin of the Kurosegawa tectonic zone.}

Ultramafic rocks in the Kurosegawa tectonic zone have the following characteristics throughout all areas from Kyushu to the Kanto Mountains.

1) There are two textural types of olivine and clinopyroxene: coarse- and finegrained.

2) Primary rock-types of the ultramafic suite are mainly harzburgite or lherzolite associated with clinopyroxenite and chromitite, and these equilibrated at about the amphibolite facies conditions. Forsterite contents in the primary olivines are mostly close to 90 .

3) The Ultramafic rocks were re-equilibrated during a second stage recrystallization at about $400^{\circ} \mathrm{C}$ to form antigorite, brucite, fine-grained olivine and acicular clinopyroxene.

4) Matrix serpentinite is finely crushed and contains crysotile/lizardite.

There are two conflicting models about the origin of the Kurosegawa tectonic zone. The first model is that the zone was originally an island arc or a microcontinent which migrated northward and converged with a subduction zone where Jurassic tectonic belts, consisting of the Sanbagawa and Chichibu accretion complexes, were formed (Maruyama et al., 1984); on this scheme, serpentinite in the Kurosegawa zone was tectonically emplaced as cold diapirs uprising to the fragmented island arc. The second model is that the Kurosegawa tectonic zone was an exotic terrain that was brought to its present position by a transform motion, with the associated Cretaceous sediments (Fig. 2) deposited in strike-slip basins (Taira et al., 1983). Tashiro $(1985,1986)$ studied bivalve faunas in the Cretaceous sediments occurring along the Kurosegawa tectonic zone. Because of differences between bivalve species in the southern side of the zone and those in the northern side, he concluded that the Kurosegawa tectonic zone was formed by a left-lateral fault with displacement of about $1,000 \mathrm{~km}$.

It is difficult to believe that the ultramafic rocks underwent antigorite-brucite metamorphism in their present locations since they are distributed sporadically for $1,000 \mathrm{~km}$ from the Kanto Mountains to Kyushu, and the associated rocks have not been affected by this metamorphism. The inconsistency of metamorphism across the two groups of rocks can be explained only if the ultramafic rocks originally were positioned at another site, without any close association with Siluro-Devonian sediments, granitic rocks and high-grade metamorphic rocks, and were metamorphosed in a area with length far shorter than that of the present Kurosegawa zone. If we assume that the ultramafic suite was metamorphosed within a 
restricted area before including other exotic rocks, it will be possible to explain the present association with the exotic blocks and the elongated nature of the Kurosegawa tectonic zone, as follows.

The ultramafic rocks were originally located in the upper mantle. Probably after nearsurface emplacement and partial serpentiniza. tion, they were metamorphosed to antigoritebrucite rocks and antigorite-bearing peridotites. Subsequently, they became associated with, or included, Silurian-Devonian sediments, granitic and high grade metamorphic rocks with ages of about $400 \mathrm{Ma}$. During left-lateral displacement by strike-slip faulting in Early Cretaceous time (Tashiro, 1985, 1986), they were converted into chrysotile/lizardite rocks within horizontal shearing systems which enclosed large slivers of the surrounding Chichibu formations. The Cretaceous sediments, now associated with the ultramafic rocks, were formed as strike-slip basin deposits, as suggested by Taira et al. (1983). Absence of the SiluroDevonian sediments, and of rocks with isotope ages of ca. $400 \mathrm{Ma}$, in the eastern part of the Kurosegawa tectonic zone is explained by the difficulty for this less mobile material to be transported laterally further to the east. This concept implies that all the members of the zone were originally located on the western side, and that the highly mobile serpentinites together with small bodies of the ultramafic primary lithologies (peridotite, clinopyroxenite, chromitite and rodingite) were translated further east during the strike-slip faulting, while large bodies of the granitic and high-grade metamorphic rocks were not moved far from their original site. This hypothesis is supported by the regional distribution of the granitic rocks, high-grade metamorphic rocks and Siluro-Devonian sediments which are common in Kyushu and Shikoku, but so far have not been reported from eastern Kii to the Kanto
Mountains.

Hayase and Nohda (1969) obtained a mineral age for the granitic rocks from Kyushu to the western Kii Peninsula. All the data from various localities were plotted in a isochron, which has a high regression, with an age of $417 \pm 5 \mathrm{Ma}$ (recalculated as $l=1.42 \times 10^{-11} / \mathrm{yr}$ ). This suggests that the granitic rocks were comagmatic and originally formed at one local. ity or within a small area. Metamorphic rocks, except for the high-pressure types, are amphibolite to granulite. If they originated from an island arc or a microcontinent as inclusions within serpentinite, such a variety of rock-types would be expected. As the serpentinites do not seem to have any particular lithology as a majority of inclusions, it is reasonable to assume that the high-grade metamorphic rocks were also located in a narrow area and were subsequently crushed into small parts and re-distributed during the strike-slip faulting.

Assuming that the ultramafic rocks came from a restricted site and that terrains on the oceanic side were more actively displaced than those on the continental side, the present distribution of lithologic units within the Kurosegawa tectonic zone suggest that the strike-slip fault was left-lateral with displacement of at least $1,000 \mathrm{~km}$. Although Taira et al. (1983) and Tashiro $(1985,1986)$ did not discuss the rock-types in the Kurosegawa association, the scheme presented here is similar to their transform model as an origin for the Kurosegawa tectonic zone. It was difficult, if not impossible, for the island arc or microcontinent model to explain the following features : how a narrow zone $1,000 \mathrm{~km}$ in length collided almost parallel to the Sanbagawa and Chichibu belts; how the ultramafic rocks, either before or after the collision, were equilibrated under the same conditions to form antigorite-brucite assemblages along the whole $1,000 \mathrm{~km}$ distance; and 
how ultramafic rocks in the colliding island arc or microcontinent had the same chemical characteristics and thermal histories throughout such an elongated system. These anomalies do not arise with the model proposed in this paper.

Maruyama (1981) and Maruyama et al. (1984) regarded the most abundant sedimentary formations in the Kurosegawa zone, although similar in age and content to those in the Chichibu belt, as belonging separately to the Kurosegawa tectonic zone and totally unrelated to the Chichibu formations. According to their island arc or microcontinent model, all tectonic blocks and slivers in the mélange were treated as originating from the island arc or microcontinent, and were thus quite distinct from the Chichibu formations. It is clear that the definition of lithologic membership within the Kurosegawa tectonic zone now seems to depend on accepting a model for the origin of the Kurosegawa zone. In this paper it is consid. ered that the sedimentary formations mentioned above were originally members of the Chichibu belt and were accidentally mixed with the serpentinites during the strike-slip faulting. If the associated rocks are defined as members of the Kurosegawa tectonic zone before the strike-slip movemet, then formations similar to those in the Chichibu belt are excluded.

Acknowledgements: The author is very gratefull to Prof. R.N. Brothers, Dr. S. Saito and Prof. A. Taira for their critical comments and readings of this manuscript. In addition, he would like to thank petrology staffs in Kyoto University and in University of Tokyo for their critical comments.

\section{References}

Aiba, K. (1982), Sanbagawa metamorphism of the Nakatsu-Nanokawa district, the northern subbelt of the Chichibu belt in western central
Shikoku. J. Geol. Soc. Japan, 88, 875-885 (in Japanese with English abstract).

Black, P.M. (1974), Oxygen isotope study of metamorphic rocks from the Ouégoa district, New Caledonia. Contrib. Mineral. Petrol., 47, 197-206.

Dietrich, V.V. and Peters, T. (1971), Regionale Verteilung der Mg-Phyllosilikate in den Serpentiniten des Oberhalbsteins. Schweiz Mineral. Petrogr. Mitt., 51, 320-348.

Dungan, M.A. (1977), Metastability in serpentineolivine equilibria. Amer. Mineral., 62, 10181029.

Dunham, A.C. and Wilkinson, F.C.F. (1978), Accuracy, precision and detection limits of energydispersive electron-microprobe analyses of silicates. $X$-ray Spectrometry, 7, 50-56.

Dunham, A.C. and Wilkinson, F.C.F. (1980), The suitability of energy-dispersive electron-microprobe analysis for the investigation of stainless steels. $X$-ray Spectrometry, 9, 8-12.

Frost, B.R. (1975), Contact metamorphism of serpentinite, chloritic blackwall and rodingite at Paddy-Go-Easy Pass, Central Cascades, Washington. J. Petrol, 16, 272-313.

Hayase, I. and Ishizaka, K. (1967), Rb-Sr dating on the rocks in Japan (1)-South Western JapanJ. Japan. Assoc. Min. Petr. Econ. Geol., 58, 201212 (in Japanese with English abstract).

Hayase, I. and Nohda, S. (1969), Geochronology on the "Oldest Rock" of Japan. Geochem. J., 3, 45-52.

Hayashi, H. (1968), Chemical characteristics of the serpentinites in Shikoku. J. Japan. Assoc. Min. Petr. Econ. Geol., 59, 60-72 (in Japasene with English abstract).

Hirano, H. and lizumi, S. (1973), Ultramafic rocks of the Chichibu belt in the western part of the Kanto mountains, central Japan. J. Japan. Assoc. Min. Petr. Econ. Geol., 59, 60-72 (in Japanese with English abstract).

Hirokawa, O. (chief ed.) (1978), Geological map of Japan, $1: 1,000,000$ (2nd Ed.). Geological Survey of Japan.

Hoffman, M.A. and Walker, D. (1978), Textural and chemical variations of olivine and chrome spinel in the East Dover ultramafic bodies, south-central Vermont. Bull. Geol. Soc. Amer., 89, 699-710.

Hsiu, K.J. (1968), Principles of mélange and their bearing on the Franciscan-Knoxville paradox. Bull. Geol. Soc. Amer., 79, 1063-1074.

Ichikawa, K., Ishii, K., Nakagawa, C., Suyari, K. and Yamashita, N. (1956), Die Kurosegawa- 
zone. J. Geol. Soc. Japan, 62, 82-103 (in Japanes with German abstract).

Inoue, M. (1974), Geologic structures of the Chi* chibu terrain in the Kanto mountainous land, Japan. J. Fac. Sci. Univ. Tokyo, II, 19, 1-25.

Ishizuka, K. (1972), Rb-Sr dating on the igneous and metamorphic rocks of the Kurosegawa tectonic zone. J. Geol. Soc. Japan., 78, 569-575 (in Japanese with English abstract).

Ivanov, O.N. and Baratov, Sh.K. (1974), Serpentine mélange of the Khatyrka river basin in the Koryak Mountains. Doklady Akad. Nauk SSSR, 214, 56-58.

Johannes, W. (1968), Experimental investigation of the reaction forsterite $+\mathrm{H}_{2} \mathrm{O} \rightarrow$ serpentine and brucite. Contrib. Mineral. Petrol., 19, 309-315.

Kunugiza, K. (1984), Metamorphism and origin of ultramafic bodies of the Sanbagawa metamor. phic belt in central Shikoku. J. Japan. Assoc. Min. Petr. Econ. Geol., 79, 20-32 (in Japanese with English abstract).

Maruyama, S. (1981), The Kurosegawa mélange zone in the Ino district to the north of Kochi City, central Shikoku. J. Geol. Soc. Japan, 87, 569-583.

Maruyama, S., Banno, S., Matsuda, T. and Nakajima, T. (1984), Kurosegawa zone and its bear. ing on the developement of the Japanese islands. Tectonophys., 110, 47-60.

Matsumoto, T., Obata, I, Tashiro, M., Ohta, Y., Tamura, M., Matsukawa, M., Tanaka, H. (1982), Correlation of marine and non-marine formations in the Cretaceous of Japan. Kase$k i, 31,1-26$.

Mercier, JC.C. and Nicolas, A. (1975), Tectures and fabrics of upper-mantle peridotites as illustrated by xenoliths from basalts. J. Petrol., 16, 454-487.

Moody, J.B. (1976), Serpentinization: a review. Lithos, 9, 125-138.

Mori, T. and Banno, S. (1973), Petrology of peridotite and garnet clinopyroxenite of the $\mathrm{Mt}$. Higashi-Akaishi mass, central Shikoku, Japan-subsolidus relation of anhydrous phases. Contrib. Mineral. petrol., 41, 301-323.

Mori, T. and Green, D.H. (1978), Laboratory duplication of phase equilibria observed in natural Iherzolite. J. Geol., 86, 83-97.

Nakamura, Y., Kushiro, I. (1970), Compositional relation of coexisting orthopyroxene, pigeonite and augite in a tholeiitic andesite from Hakone Volcano. Contrib. Mineral. Petrol., 26, 265-275.

Nitsch, K.H. (1971), Stabilitätsbeziehungen von
Prehnite- und Pumpellyite-haltigen Paragenesen. Contrib. Mineral. Petrol, 30, 240260.

Peters, T.J. (1968), Distribution of $\mathrm{Mg}, \mathrm{Fe}, \mathrm{Al}, \mathrm{Ca}$ and $\mathrm{Na}$ in coexisting olivine, orthopyroxene and clinopyroxene in the Totalp serpentinite (Davos, Switzerland) and in the alpine metamorphosed Malenco serpentinite (N. Italy). Contrib. Mineral. Petrol., 18, 65-75.

Pinsent, R.H. and Hirst, D.M. (1977), The metamorphism of the Blue river ultramafic body, Cassiar, British Columbia, Canada. J. Petrol., 18, 567-594.

Saito, Y. (1985), Jurassic geologic framework in the Japanese Islands. In Tectonostratigraphic terranes of the Circum-Pacific region edited by D.G. Howell, 401-408.

Saleeby, J. (1979), Kaweah serpentinite mêlange, southwest Sierra Nevada foothills, California. Bull. Geol. Soc, Amer., 90, 29-46.

Statham, P.J. (1979), A ZAF procedure for microprobe analysis based on measurement of peak-to-background ratios. In Microbeam analysis edited by D.E. Newbury, 247-253.

Taira, A., Saito, Y. and Hashimoto, M. (1983), The role of oblique subduction and strike-slip tectonics in the evolution of Japan. In Geodynamics of the Western Pacific-Indonesia region edited by T.W.C. Hilde and S. Ueda. Am. Geophys. Union Geodyn. Ser., II, 303-316.

Tashiro, M. (1985), The Cretaceous system of the Chichibu belt in Shikoku-on the Early Cretaceous lateral fault in the Chichibu belt. Kaseki, 38, 23-35 (in Japanese with English abstract).

Tashiro, M. (1986), Paleobiogeography and paleoecology of the Cretaceous system of Southwest Japan. Kaseki, 41, 1-16 (in Japanese with English abstract).

Toriumi, M. (1975), Petrological study of the Sanbagawa metamorphic rocks. Univ. of Tokyo, Bull., 9, $99 \mathrm{pp}$.

Trommsdorff, V. and Evans, B.W. (1972), Progres. sive metamorphism of antigorite schist in the Bergell tonalite aureole (Itary). Amer. J. Sci., 272, 423-437.

Trommsdorff, V. and Evans, B.W. (1980), Titanian hydroxyl-clinohumite: Formation and breakdown in antigorite rocks (Malenco, Italy). Contrib. Mineral. Petrol., 72, 229-242.

Vance, J.A. and Dungan, M.A. (1977), Formation of peridotites by deserpentinization in the Darrin gton and Sultan areas, Cascade Mountain, 
Washington. Bull. Geol. Soc. Amer, 88, 14971508.

Wenner, D.B. and Taylor, H.P.Jr. (1971), Temperatures of serpentinization of ultramafic rocks based on $\mathrm{O}^{16} / \mathrm{O}^{18}$ fractionation between $\mathrm{co}$ existing serpentinite and magnetite. Contrib. Mineral. Petrol., 32, 165-185.

Wenner, D.B. and Taylor, H.P.Jr. (1973), Oxygen and hydrogen isotope studies of the serpentinization of ultramafic rocks in oceanic environments and continental ophiolite complexes. Amer. J. Sci., 273, 207-239.
Yamagiwa, N. (1957), Stratigraphy and geological structure of the eastern area of Shima Penin. sula. J. Geol. Soc. Japan, 63, 263-272 (in Japanese with English abstract).

Yokoyama, K. (1977), Ultramafic and related rocks in the Sanbagawa metamorphic belt. Ph. D. Thesis, Univ. of Tokyo, $186 \mathrm{pp}$.

Yokoyama, K. (1982), Nikubuchi peridotite body in the Sanbagawa metamorphic belt; thermal history of the "Al-pyroxene-rich suite" peridotite body in high pressure metamorphic terrain. Contrib. Mineral. Petrol., 73, 1-13.

\section{黒瀬川帯の超苦鉄質岩}

\section{横山一己}

黑瀨川带の超苦鉄質岩中には異なった時期を示す 2 種類の形態と化学組成をるつかんらん石と単斜輝石 がある。超苦鉄質岩の源岩は主にハルッバーシャイトかレルゾライトで角閃岩相程度の条件で平衡にあっ た。その後これらの岩石は約 $400^{\circ} \mathrm{C}$ で変成された。紀帇半島東部から関東山地にかけて秩父帯中にある超 苦鉄質岩は黒瀬川帯のものと同じ形態と化学組成を示し黑瀬川帯の延長と考えられる。超苦鉄質岩と黑瀬 川帯を構成する他の岩石は，元来は，現在の位置上り西万にあり，白要紀前期の左横ずれ断層により破砕 され東方に運ばれた。その際滑りやすい蛇紋岩化した超苦鉄質岩は関東山地まで達したが，滑りにくい花 南岩等は西方に残された。 